\title{
Housing Industry Readiness Factors and Indicators to Implement Green Building Development
}

\author{
Christy P. Gomez ${ }^{1}$, Gordon Ting Tiew Yung ${ }^{1}$ \\ ${ }^{1}$ Faculty of Technology Management and Business, Batu Pahat, Malaysia \\ *Corresponding E-mail: cpgomez21@gmail.com
}

Received 15 May 2017; Revised 05 June 2018; Accepted 10 April 2018

DOI: https://10.30880/ijscet.2018.09.01.004

\begin{abstract}
The importance of having a sustainability agenda has stimulated greater interest for green construction. However, Malaysia is still moving at a slow pace in green building development as compared to other Asia Pacific countries. This paper focuses on investigating the housing industry's key stakeholders' readiness factors with regards to the implementation of the green building concept. The first aspect being the relative importance of the design teams' competencies and commitment in designing green building projects; the second being the factors affecting developer's decision to procure green buildings; and most importantly and thirdly, the readiness of the housing industry to implement green building development. A questionnaire survey data collection process was undertaken with 'design consultants and architects' for the first objective and 'housing developers' for the second and third objective. It was found that the most important competencies of the design team in designing green buildings are: knowledge relevant to green design; attention to green design and construction details and offering suggestions to improve green design. The key 'commitment' readiness factor identified is the commitment of the architect to produce green design. Whilst the key factors affecting clients' decisions to procure green buildings are: experience on green buildings; clients' knowledge on green buildings; commitment of client organizations to provide finance for green buildings; reliability and quality of specifications, and leadership skills and responsibility of constructor. Clearly, the readiness of the housing industry in the development of green buildings is not at a high level, with $41 \%$ of the respondents on average acknowledging that the readiness level of their companies is low.
\end{abstract}

\section{1 .0 Introduction}

The concerns regarding the negative impact of climate change and the importance of having a sustainability agenda has stimulated greater interest for green construction. However, Malaysia is still moving at a slow pace in green building developments as compared to other Asia Pacific countries such as Japan, Singapore and Australia. Green technology has played an important role to reduce the negative impact of the built environment on human health and the natural environment. It is noted by Hes (2005), that design is one of the highest impact areas on 'green' performance of the built environment. It is clear that green specification achievement and design achievement are two key elements to achieve a sustainable future in the building industry. Although it is widely acknowledged that green buildings are beneficial to our environment and society, however the key to moving forward to going green has been rather challenging for all key stakeholders, including the government, private sector owners, designers and contractors. It is noted by Abidin (2010) that in Malaysia, green construction development is still at an early stage and faces great challenges to penetrate the market widely.

Green building refers to the quality and characteristics of the actual structure created using the principles and methodologies of sustainable construction (Kibert and Grosskropf, 2005). The aim of this paper is to highlight the issues related to implementation of the concept of green building generally, and more specifically that of residential green buildings or green homes. The construction industry is Malaysia contributes significantly to the economic growth of the country. Based on 
Keywords: Sustainability, Green building procurement, Key stakeholder commitment and competency, Readiness factor

readily available data from the Department of Statistics Malaysia, the value of construction work done in Malaysia in Q3 2017 grew at 8.1\% (Q2 2017 was 11.2\%) to record RM34.5 billion, with residential construction having a percentage share of $28.2 \%$ in Q2 2017. This very important building sector is often subsumed under the general context of green building and needs to be gradually differentiated, as housing is a basic need that can enhance quality of life in a significant manner.

In reviewing extant literature, following Fazdiliel et al. (2013), it is clear that in the context of the building sector, the concept of sustainability has been described interchangeably using many terms including 'ecological building', 'energy efficient building', 'high performance building' and 'green building'. In this paper, green building refers to the quality and characteristics of the actual structure created using the principles and methodologies of sustainable construction (Kibert and Grosskropf, 2005). Green buildings are structures that preserve the natural surroundings and uses resources efficiently in order to build a healthy lifestyle and well-built buildings. According to Ken Yeang, a successful green building is one that integrates seamlessly with the natural systems in the biosphere, with minimal destructive impact on these systems and maximum positive impact (Greig et al., 2012). A "green" building places a high priority on health, environmental and resource conservation performance over its life cycle. According to Winston (2010), sustainability demands that houses be built in a higher quality, have access to green space, close to good public transport, using design techniques to increase energy efficiency of dwelling, provide facilities that promote social contact and have a clean and safe residential environment.

Residential property that is sustainable requires new priorities which complement the classical building design concerns of economy, utility, durability, and delight. Specifically, green design emphasizes a number of new environmental, resources and occupant health concerns such as (Hui, 2002):

i. reducing human exposure to noxious materials.

ii. conserving non-renewable energy and scarce materials. iii.

minimizing life-cycle ecological impact of energy and materials used. iv.

using renewable energy and materials that are sustainably harvested. v.

protecting and restoring local air, water, soils, flora and fauna.

vi. supporting pedestrians, bicycles, mass transit, and other alternatives to fossil-fueled vehicles.

In a more precise and simplistic sense, green homes can be said to be constructed with the following more common green features and characteristics in order to reduce the residential sector's impact on the environment:

i. Installation of rainwater harvesting system.

ii. Use of low carbon-emitting construction materials, such as low volatile organic compound (VOC) paints, recycled content wall and floor tiles.

iii. Use of solar roof shingles to generate renewable energy. iv. Double-glazed glass panels to reduce heat transmission.

v. Use of low-flow water features such as water efficient sanitary appliances and tap fittings. vi. Lush and landscaped greenery with water features (pond). 
vii. Equip with energy efficient appliances such as LED lights, and air conditioning systems.

It is noted by Nazirah et al. (2013) that in Malaysia, the continuous economic growth since independence in 1957 led to extensive development of buildings and infrastructures with little regard to the environment. According to Birkeland (2002), designers, developers and users of buildings could reduce considerably the quantities of pollutants entering the environment through the careful choice of environmentally friendly materials, the use of an ecological design approach, and sensible care and use of the building. It is undeniable that the housing industry is one of the major sectors of the construction industry. Housing is a basic need that can enhance the quality of life. The construction sector contributes to the nation's economic growth through its linkages with the other sectors including the service and manufacturing of construction materials sectors. Nazirah et al. (2013) are of the view that transition from conventional to sustainable approach in housing development will require some time as it involves changes from different facets in the industry ranging from individual, organization to industry level.

There is a general perception in Malaysia that financial constraint is the main factor impeding the implementation of green building concept (Abidin, 2009). Green building practices are believed to increase project cost because they need to have higher upfront capital. Higher cost means higher price. In considering to pursue the green building approach in the projects, obviously developers need to be convinced that there is a market for it because the cost will be transferred to the buyers or end users. New approaches are perceived as risky, and the developers are forced to rely on unofficial third party cost information which reduces their level of confidence.

Notwithstanding the challenges being faced, the way forward is to reduce the negative impact of constructing buildings; and the implementation of green buildings compared to traditional buildings is seen as a step in the right direction in the journey towards attaining sustainability. Within this context of promoting the development of green buildings it must be noted that there are a number of important trends favouring the continued growth of green buildings in Malaysia, they are (CIDB, 2007):

\section{i. National Environment Policy ii. Construction Industry}

Master Plan 2006-2015 (CIMP) iii. Tax Incentives iv. Loan

\section{Incentives}

In order to identify the level of sustainability of a building, a certain form of standard assessment is required. During the last ten years considerable research has been focused on the development of systems to assess the environmental performance of buildings. Various evaluation methods, assessment tools, and certification systems were developed worldwide (MingChin and Chiung-Yu, 2006). Several of these systems have gone the next step, resulting in a labelling system that indicates clearly the building's approximate performance to end users (Maisarah et al., 2005). Building rating system has been developed as a way to formalize and regulate the use of labels for certified green buildings. Rating systems are essentially lists of "options" which count towards a point system within a limited set of categories associated with the building project-usually site selection, energy, indoor environmental air quality, materials selection, and reuse and recycling. Malaysia differs markedly in these areas and thus understandable the rating priorities differ likewise compared to that used in other countries.

In Malaysia, the most common green building rating tool is the Green Building Index (GBI) rating tool system. GBI has been launched in Malaysia since 2009 and it provides an assessable differentiation to promote environment-friendly buildings for the future of Malaysia. The GBI rating tool accomplishes this by rating all buildings across six categories of concern using key environmental attributes in each category. The six major aspects for rating green buildings are energy efficiency, indoor environmental quality, sustainable site planning and management, material and resources, water efficiency and innovation. Tan (2009), considers GBI to be a 
benchmarking rating system that incorporates internationally recognized best practices in environmental design and performance. There are only 650 buildings certified under GBI as of 2015 (GBI, 2017). Hence, it can be concluded that green buildings are not a common practice in Malaysia because of the unique challenges these programs face.

\subsection{Literature Review}

The concept of green or sustainable buildings is not new, but the technologies associated with the concept have evolved and matured over time (Emmit and Gorse, 2006). Contractor's performance has been a major issue on traditional projects and the problems can be further complicated in green building construction. It is necessary to find out the factors affecting clients and in their decision to build green buildings as opposed to traditional buildings. As green building construction continues to grow and gain popularity, it is necessary to better understand the competencies that architects should possess to design green construction projects.

\subsection{Understanding Green Building and Sustainability}

The terms 'green' and 'sustainable' are often used interchangeably but there are fundamental differences between them (Building Science, 2008). Sustainable construction has been described most comprehensively as the ecological, social and economic issues of a building in the context of its community (Kibert and Grosskropf, 2005). It refers precisely to the goal of designing and constructing buildings that have no net impact on the environment, such that a total built environment composed of similar buildings could coexist with the world's ecological balance indefinitely (Building Science, 2008).

\subsubsection{Green Building Elements}

The process of designing a green building is different from that of conventional design (Chaffin, 1998). It involves:

i. Selection of the Appropriate Materials: The proper selection of materials has a major influence on the success or failure of a green building (Chaffin, 1998). Material selection is also often one of the most visible and attention-getting green aspects of a project.

ii. Design for a Healthful Indoor Environment: Green buildings are designed to reduce breathing problems by providing good ventilation to allow fresh air to flow through the house, installing an exhaust system for radon gas, avoiding wood products which contain formaldehyde and sealing those which do, using low or no VOC interior paint, solvent-free finishes, and solvent-free construction adhesives.

iii. Lighting for Green Building Construction: The most sustainable lighting is natural daylight. It is not only a free renewable resource but it also has well-documented health benefits. Careful architectural design is required to maximize natural light in a building while maintaining indoor temperature regulation and reducing direct light glare. 


\subsection{Implementation of Green Buildings}

The construction industry plays an important role in sustainable development because it uses the earth's resources to build the buildings where people live, work, and play (Glavinich, 2008). Sustainable construction is a way for the building industry to move towards achieving sustainable development (Faridah et al, 2006). Green building has become one of the most efficient practice and also a measure to pursue the objective of a sustainable built environment (Ming-Chin and Chiung-Yu, 2006). However, various barriers and factors affect the implementation of green buildings.

\subsubsection{Challenges to the Adoption of Green Building Practices}

According to research done by Reza et al. (2011), the critical challenge in the adoption of green buildings in Malaysia is to create a paradigm shift in environmental issues for all Malaysians, especially those in the construction industry. The focus way back in 2011 was on the lack of awareness, even that of architects and consultants. Additionally, clients have been repeatedly mentioned in extant literature as the key issue to the slow progress of being involved in green buildings. Low investments and participation from the Government and private companies in the green building movement also were noted as posing a challenge to building practitioners to design and build green buildings more efficiently. Whilst the architects were noted to be additionally faced with the dilemma regarding a lack of competent specialists to provide useful data and advice on green building systems and concepts. Hayles and Kooloos (2008), categorize the challenges facing the adoption of green building by reviewing extant literature into five distinct categories, namely: cost; information; design processes; construction processes; and materials and technology. In summary, they are as follows:

\section{Capital Cost}

The general industry view is that green buildings come at a premium, with a minimal connection made between the up-front capital costs of construction and the operating costs, once the building is completed. Economic barriers to sustainable design can include: lack of information about inherent long-term economic benefits of sustainable buildings; lack of integration among various incentive programs (rebates, loans, technical assistance, and recognition programs); reality that first cost is the overriding concern among financial institutions and investors; and the inherently the conservative nature of the building industry.

\section{Information Gathering}

There is a lack of research on the performance of green buildings. There is also concern that the complexity of some green designs (technological high performance) may bring about obsolescence earlier than conventional design. There is also disagreement as to: what the minimum performance standards should be; which activities are considered to be environmentally stressful; what the economics are; and how to evaluate or measure 
sustainable building. Attempts to integrate the vast amount of information currently available and effectively disseminate it have so far fallen short.

\section{The Design Process}

There appears to be limited understanding of available green options by design professionals. This includes: insufficient knowledge to produce specifications; a lack of available high performance materials; problems in obtaining approval for new technologies complying with building codes; uncertainty about approvals; regulatory barriers to adoption of technologies and labour issues due to potential labour-saving measures. There is no standard assessment criteria for products that allows them to be directly evaluated, and therefore design professionals have to invest a lot of time in assessing potential materials and technology.

\section{The Construction Process}

Building on the issues described in the design process, the construction process can also be a difficult one. Issues include a lack of knowledge and consequently skilled labour to install and maintain new technologies (and minimal availability of training for the industry). Additionally, there is limited infrastructure to handle and make available recycled material from deconstruction, thereby making costs prohibitive to consider building green buildings.

\section{Materials and Technology}

The process of transporting materials via road, sea or air can leave a trail of pollution, making it more sustainable to use local products. Issues arise as to what is considered to be the most appropriate environmentally friendly product for a particular purpose that is not available locally, thereby making materials selection extremely complex. Most architects find it difficult to establish the embodied energy or life cycle costs of a particular product. Although the process of Life Cycle Analysis (LCA) exists to make this evaluation, a number of issues arise, such as the incentive for suppliers to perform this analysis on their products. This is likely to be consumer or industry demand driven, hence if the results are not positive in environmental terms they are unlikely to be published.

\subsubsection{Barriers Affecting the Implementation of Green Buildings}

Meryman and Silman (2004) identified three primary barriers towards accepting specification with green considerations. They identified economic concern as the main barrier encountered by practitioners, whereas policy decisions and technical issues were the two additional main barriers (see Table 2.4). 
Table 2.4: Potential Barriers Faced in Delivering Green Projects (source: Meryman and Silman, 2004)

\begin{tabular}{|c|c|}
\hline A & ECONOMIC CONCERN \\
\hline $1 \mathrm{a}$ & $\begin{array}{l}\text { 1. Cost Issue: } \\
\text { Additional costs due to green requirements } \\
\text { 2. Time Issue: } \\
\text { Possible delays due to green requirements }\end{array}$ \\
\hline $\mathrm{B}$ & TECHNOLOGICAL CONCERN \\
\hline $\begin{array}{l}1 \mathrm{a} \\
1 \mathrm{~b}\end{array}$ & $\begin{array}{l}\text { 1. Technical Issue: } \\
\text { Aesthetically less pleasing } \\
\text { Uncertainty in the durability of green materials }\end{array}$ \\
\hline $\mathrm{C}$ & POLICY CONCERN \\
\hline $\begin{array}{l}2 \mathrm{a} \\
2 \mathrm{~b} \\
2 \mathrm{c} \\
2 \mathrm{~d} \\
2 \mathrm{e} \\
2 \mathrm{f} \\
2 \mathrm{~g}\end{array}$ & $\begin{array}{l}\text { 1. Contractual Issue: } \\
\text { Uncertainty in the liability for the final works } \\
\text { Unachievable specification requirements } \\
\text { Possible ambiguities and conflicts between clauses } \\
\text { Possible disputes on specification compliance } \\
\text { 2. Management Issue: } \\
\text { Limited support from the senior management } \\
\text { Limited knowledge on green technology and materials } \\
\text { Limited availability and reliability of green suppliers } \\
\text { Low flexibility for alternatives or substitutes } \\
\text { Limited tools to assess the green performance of a completed building } \\
\text { Resistance from interested groups or market players in the market } \\
\text { Unwillingness to change the conventional way of specifying }\end{array}$ \\
\hline
\end{tabular}

\subsubsection{Factors Affecting the Implementation of Green Buildings}

There are a number of key factors that have been identified by various researchers affecting the implementation of green buildings. However, those that are found to be crucial are those related to the client/developer, the key stakeholder in the preconstruction phase.

\subsubsection{Factors Affecting the Decision to Build Green Buildings Related to Clients/Developers}

Elforgani et al. (2014) identified seven key client's qualities affecting the decision by clients/developers to build green buildings. They were: i. Clients' knowledge on green buildings ii. Clients' experience on green buildings iii. Clients' commitment to green buildings iv. Clients' capability of managing design process

v. Client communication effectiveness with design team vi.

Commitment of client organization to provide finance for green building vii.

Maintaining active participation in green design process.

In another research done by Lam et al. (2009), five factors were identified as affecting the implementation of green specifications. They were: i. green technology and techniques ii. reliability and quality of specification 
iii. leadership and responsibility iv.

stakeholder involvement guide, and v.

benchmarking systems.

\subsubsection{Factors Related to the Design Team's Decision to Build Green Buildings as Opposed to Traditional Buildings}

Green design performance greatly depends on design team attributes. Hes (2005) and Elforgani et al. (2014) note that design is one of the highest impacting areas on 'green' performance of the built environment. According to Elforgani et al. (2014), there are two key variables that can affect the final decision to implement green building concept; it is the competency and commitment of the design team. Whilst Olufunto and Olatunde (2013) emphasize that the role of the architect is important in determining the success of green projects as they are most involved during the design process of green buildings. According to research done by Elforgani et al. (2014), a list of 12 design team green attributes variables are identified as below:

i. $\quad$ Knowledge relevant to green design ii.

Knowledge of green design assessment tools iii.

Skills of using design programs iv. Interpret client needs into efficient green design

v. Attention to green design and construction

details vi. Speed in Producing Green Design

Drawings vii. Ability in overcoming green design

difficulties viii. Offering suggestion to improve green

design ix. Interest in the green design assignments

x. Commitment level of the architect to produce green design xi. Commitment level of Mechanical and Electrical engineers to implement green energy xii. Commitment of Quantity Surveyor to select green materials.

\subsection{Readiness of Construction Industry to Implement Green Building Projects}

Holt (2000) suggested that organizational readiness is a necessary precondition to the organization to succeed in facing organizational change. Therefore, the organization needs to carry out an assessment to examine the current stage of organizational readiness to embark on the organizational change. This kind of exercise facilitates the organization to recognize the readiness level and identify the gaps that may exist (Holt et al., 2007). However, for the purposes of obtaining a snap-shot examination of housing developer companies' readiness factors to develop green building projects, two questionnaire research instruments based on reviewing extant literature was used and examined within the context of commitment and competence of design team factors and housing developers influence factors (see Table 4.1, 4.2 and 4.3). This was necessary to be undertaken, to present a contextualized investigation regarding the factors affecting the implementation and development of green buildings. This preliminary research, paves the way for more 
intensive investigations regarding the current issues related to readiness of the housing industry in the development of green residential buildings.

\subsection{Methodology}

There has been much research focused on the challenges faced by contractors and the factors affecting their performance in the construction of green building projects, whilst little work has been focused on exploring the dynamics related to the issue of low level of implementation of green buildings from key stakeholder perspective at the pre-construction stage. One such example of research regarding the stakeholder issues at the construction phase is the research carried out in Ghana by Ofori (2012). He concluded the problems which face the Ghanaian construction industry are similar to those which are commonly seen in reports on the industries in other developing countries. They include the inability to secure adequate working capital, inadequate management, insufficient engineering capacity and poor workmanship. However, this paper investigates the readiness factors of the key housing industry key stakeholders in Malaysia in the development of green residential buildings.

\subsection{Data Collection Strategy}

Two different sets of questionnaires were designed to achieve the different objectives. "Questionnaire A" was designed to achieve the first objective and the second set, "Questionnaire B" was designed to achieve the second and third objectives. The target respondents for Questionnaire A were architects and design consultants clients and the target respondents for Questionnaire B were housing developers located in Johor Bahru District in Malaysia. All the questionnaires were distributed via Google Docs and Survey Monkey. Questionnaire A was designed and delivered using Survey Monkey while Questionnaire B was designed and delivered using Google Docs. There were 20 consultants and architects who answered Questionnaire A and 22 clients/developers who answered Questionnaire B, out of a total of 150 sets of Questionnaire A and 150 sets of Questionnaire B that were sent out.

The poor response rate is considered to be a major limitation of the research in terms of representativeness of the sample. However, the small sample size is attributed to using purposeful sampling, as only respondents with prior experience on green building projects were targeted as respondents. Additionally, the purposeful sampling was undertaken with developers and design consultants (including architects) whose offices were located in Johor Bahru due to the high focus on developing Iskandar Malaysia (which includes Johor Bahru district) by the Iskandar Regional Development Authority (IRDA) into a Low Carbon Society.

\subsection{Data Analysis and Results}

Descriptive statistics was used as the means to analyze the responses. The 'medium' and 'high' responses for "Relative Importance of Specific Competencies and Commitment' (see Table 4.1), 'Factors Affecting Developer's Decision to Procure Green Buildings' (see Table 
4.2) were grouped in order to ascertain the level of significance of the results - using a discretionary percentage value of total agreement above $80 \%$ considered as being significant. Whilst for ascertaining the 'Level of readiness of clients/housing developer to implement green building development', the analysis as tabulated (see Table 4.3) was used to interpret the findings.

Table 4.1 shows the summary of the important competency indicators of architects and consultant designers for the procurement of green residential buildings. Amongst the total 12 competencies, $\mathrm{C} 1, \mathrm{C} 5$ and $\mathrm{C} 8$ had the highest rate of importance with $100 \%$ response to signify these three competencies as being the most important. $\mathrm{C} 1$ being: Knowledge relevant to green design and $\mathrm{C} 5$ being: Attention to green design and construction details, and C8 being: Offering suggestions to improve green design. The lowest level of importance indicated by respondents are C6: Speed of producing green design drawings. The important commitment indicators of architects and consultant designers in designing green building projects are C10: Commitment level of the architect to produce green design and C11: Commitment level of Mechanical and Electrical engineers to implement green energy concepts. Whilst the lowest level of importance indicated is C12: Commitment of Quantity Surveyor to select green materials.

Table 4.1: Relative Importance of Specific Competencies and Commitment Indicators

\begin{tabular}{|c|c|c|c|c|}
\hline \multirow[b]{2}{*}{ Competencies } & \multicolumn{4}{|c|}{ Categories of Relative Importance } \\
\hline & Low & Medium & High & $\begin{array}{l}\text { Medium } \\
\text { \& High }\end{array}$ \\
\hline $\mathrm{C} 1$ : Knowledge relevant to green design & $0 \%$ & $5 \%$ & $95 \%$ & $100 \%$ \\
\hline C5: Attention to green design and construction details & $0 \%$ & $5 \%$ & $95 \%$ & $100 \%$ \\
\hline C8: Offering suggestions to improve green design & $0 \%$ & $5 \%$ & $95 \%$ & $100 \%$ \\
\hline C4: Interpret client needs into efficient green design & $0 \%$ & $15 \%$ & $85 \%$ & $100 \%$ \\
\hline C7: Ability in overcoming green design difficulties & $5 \%$ & $15 \%$ & $80 \%$ & $95 \%$ \\
\hline C2: Knowledge of green design assessment tools & $0 \%$ & $35 \%$ & $65 \%$ & $100 \%$ \\
\hline C9: Greater interest towards green design assignments & $0 \%$ & $50 \%$ & $50 \%$ & $100 \%$ \\
\hline C3: Skills of using green design software & $10 \%$ & $70 \%$ & $20 \%$ & $90 \%$ \\
\hline C6: Speed in Producing Green Design Drawings & $35 \%$ & $50 \%$ & $15 \%$ & $65 \%$ \\
\hline \multicolumn{5}{|l|}{ Commitment } \\
\hline $\begin{array}{l}\text { C10: Commitment level of the architect to produce } \\
\text { green design }\end{array}$ & $0 \%$ & $10 \%$ & $90 \%$ & $100 \%$ \\
\hline $\begin{array}{l}\text { C11: Commitment level of Mechanical and Electrical } \\
\text { engineers to implement green energy concepts }\end{array}$ & $0 \%$ & $40 \%$ & $60 \%$ & $100 \%$ \\
\hline $\begin{array}{l}\text { C12: Commitment of Quantity Surveyor to select } \\
\text { green materials }\end{array}$ & $35 \%$ & $35 \%$ & $30 \%$ & $65 \%$ \\
\hline
\end{tabular}

Summary of the results on the importance of the influence factors affecting client's and developer's decision to build green buildings as opposed to traditional buildings is presented in Table 4.2. Except for 4 factors, F7, F15, F16 and F17, the rest of the 17 factors were considered to be of important. F2: Client's knowledge on green buildings and F4: Client's capability of managing the design process had the highest rating of importance. 
Table 4.2: Influence Factors Affecting Developer's Decision to Procure Green Buildings

\begin{tabular}{|l|c|c|c|c|}
\hline \multirow{2}{*}{ Factors } & \multicolumn{4}{|l|}{ Categories of Relative Importance } \\
\cline { 2 - 5 } & Low & Medium & High & $\begin{array}{l}\text { Med \& } \\
\text { High }\end{array}$ \\
\hline F1: Clients' knowledge on green buildings & $18.2 \%$ & $4.5 \%$ & $77.3 \%$ & $81.8 \%$ \\
\hline F2: Clients' experience on green buildings & $0.0 \%$ & $22.7 \%$ & $77.3 \%$ & $100 \%$ \\
\hline F3: Clients' commitment to green buildings & $4.5 \%$ & $27.3 \%$ & $68.2 \%$ & $95.5 \%$ \\
\hline $\begin{array}{l}\text { F4: Clients' capability of managing design } \\
\text { process }\end{array}$ & $0.0 \%$ & $72.7 \%$ & $27.3 \%$ & $100 \%$ \\
\hline $\begin{array}{l}\text { F5: Client communication effectiveness with } \\
\text { design team }\end{array}$ & $4.5 \%$ & $22.7 \%$ & $72.7 \%$ & $95.5 \%$ \\
\hline $\begin{array}{l}\text { F6: Commitment of client organizations } \\
\text { provide finance for green building }\end{array}$ & $4.5 \%$ & $18.2 \%$ & $77.3 \%$ & $95.5 \%$ \\
\hline $\begin{array}{l}\text { F7: Maintaining active participation in green } \\
\text { design process }\end{array}$ & $27.3 \%$ & $36.4 \%$ & $27.3 \%$ & $72.7 \%$ \\
\hline F8: Availability of green technology & $9.1 \%$ & $45.5 \%$ & $45.4 \%$ & $90.9 \%$ \\
\hline F9: Reliability and quality of specifications & $4.5 \%$ & $18.2 \%$ & $77.3 \%$ & $95.5 \%$ \\
\hline $\begin{array}{l}\text { F10: Leadership skills and responsibility of } \\
\text { constructor }\end{array}$ & $4.5 \%$ & $18.2 \%$ & $77.3 \%$ & $95.5 \%$ \\
\hline F11: High Stakeholder involvement & $4.5 \%$ & $50.0 \%$ & $45.5 \%$ & $95.5 \%$ \\
\hline F12: Guide and benchmarking system & $9.1 \%$ & $40.9 \%$ & $50.0 \%$ & $90.9 \%$ \\
\hline F13: Cost concerns & $9.1 \%$ & $22.7 \%$ & $68.2 \%$ & $90.9 \%$ \\
\hline F14: Technical issues & $4.5 \%$ & $27.3 \%$ & $68.2 \%$ & $95.5 \%$ \\
\hline F15: Time concerns & $54.2 \%$ & $18.2 \%$ & $27.3 \%$ & $45.8 \%$ \\
\hline F16: Management issues & $36.4 \%$ & $31.8 \%$ & $31.8 \%$ & $63.6 \%$ \\
\hline F17: Contractual issues & $45.5 \%$ & $18.2 \%$ & $36.3 \%$ & $54.5 \%$ \\
\hline
\end{tabular}

Table 4.3 shows the summary of the level of readiness to implement green building development. The results on the average show that the level of readiness for all the elements is not high. In fact the highest level of readiness indicated by the respondents is for element E2: Company's support towards the development of green certification standards, with only $36 \%$ indication that there is a high level of readiness.

Table 4.3: Level of readiness of housing developer in green building development

\begin{tabular}{|l|c|c|c|}
\hline \multirow{2}{*}{ Elements of Readiness } & \multicolumn{3}{|c|}{ Level of Readiness } \\
\cline { 2 - 4 } & Low & Medium & High \\
\hline $\begin{array}{l}\text { E1:Readiness to create procedure to } \\
\text { apply environmental criteria }\end{array}$ & $41 \%$ & $59 \%$ & $0 \%$ \\
\hline $\begin{array}{l}\text { E2:Company's support towards the } \\
\text { development of green certification } \\
\text { standards }\end{array}$ & $41 \%$ & $23 \%$ & $36 \%$ \\
\hline $\begin{array}{l}\text { E3:Readiness to embrace green homes } \\
\text { development in terms of financial } \\
\text { security }\end{array}$ & $55 \%$ & $32 \%$ & $13 \%$ \\
\hline
\end{tabular}




\begin{tabular}{|l|c|c|c|}
\hline $\begin{array}{l}\text { E4:Company's commitment to train } \\
\text { staff for green development }\end{array}$ & $32 \%$ & $54 \%$ & $14 \%$ \\
\hline $\begin{array}{l}\text { E5:Company establishment of clear } \\
\text { lines of communication with suppliers } \\
\text { on green materials }\end{array}$ & $41 \%$ & $41 \%$ & $18 \%$ \\
\hline $\begin{array}{l}\text { E6:Readiness to integrate } \\
\text { environmental aspects in the purchase } \\
\text { of materials }\end{array}$ & $36 \%$ & $59 \%$ & $5 \%$ \\
\hline Average: & $41 \%$ & $45 \%$ & $14 \%$ \\
\hline
\end{tabular}

\subsection{Results and Discussions}

Based on Resource-based View (RBV) theory, the latent variable of competence is considered to be a key asset for competitive advantage, however the aspect of competence of the design team is viewed here in the context of being the micro factors at the operational level that need to be in place to significantly impact on developing green residential buildings. Whilst commitment is similarly a micro latent variable, which is best understood based on a human factors approach, in terms of human agency to bring about change. It is evident that results indicated that there is a high level of agreement within the 'green construction community' regarding the competency and commitment indicators for the procurement of green residential buildings as well as the high level of significance of these factors, except for: Speed in Producing Green Design Drawings and Commitment of Quantity Surveyor to select green materials. These results are important as it filters out the indicators collated from more generic literature and provides knowledge on this issue that is more specific to the housing industry.

The argument above regarding the results obtained for determining the 'Influence Factors Affecting Developer's Decision to Procure Green Buildings' applies. The outcome provides a more specific list of influence factors for the housing industry. Whilst the results of this preliminary study indicate that the readiness level to develop green residential buildings within the housing industry, based on perception data of current practice, is rather low. Although being a preliminary study with certain limitations with regards to rigour the outcome of this research does not augur well for the housing industry in particular, and for the construction industry in the broader sense. It would be timely for housing industry stakeholders to implement strategies in an integrated manner, taking into account some of the key findings of this research, to increase the level of readiness of the industry for the challenge of developing green residential buildings.

\section{References}

Abidin, Z.N. (2009). Sustainable Construction in Malaysia-Developers' Awareness. World Academy of Science, Engineering and Technology 53, 2009.

Abidin, Z.N. (2010). Investigating the awareness and application of sustainable construction concept by Malaysian developers. Habitat International, 34, pp.421-426.

Armenakis, A.A., Harris, S.G. and Mossholder, K.W. (1993). Creating readiness for organizational change. Human Relations, 46 (3) (1993), pp. 681-703 http://hum.sagepub.com/content/46/6/681.full.pdf.

Emmitt, S. and Gorse, C. (2006). Barry's Advanced construction of buildings. Singapore: Blackwell Publishing Ltd. 
Berman, A. (2001). Green buildings: Sustainable profits from sustainable developments. An unpublished report by Tilden Consulting.

Birkeland, J. (2002). Design for Sustainability : A Sourcebook of Integrated, Ecological Solutions. London, GBR: Earthscan, 2002.

Building Science. (2008). Towards Sustainability - Green Building, Sustainability Objectives and Building. America Whole House Systems Research: Building Science Corporation.

Chaffin, J.J.Jr. (1998). Green Development, Integrating Ecology and Real Estate. London:Sage Publication.

Hui, C.M. (2002). Environmental sustainability assessment of buildings using requirements in building energy codes, In Proc. of the Sustainable Building 2002 International Conference, 23-25 September 2002, Oslo, Norway.

CIDB, (2007). Construction Industry Master Plan 2006-2015 (CIMP). Construction Industry Development Board (CIDB) Malaysia, Kuala Lumpur.

Du Plessis, C. (2002). A strategic framework for sustainable construction in developing countries. In Construction Management and Economics. January 2007 25, 67-76.

Elforgani, M.S.A., Alnawawi, A. and Rahmat, I.B. (2014). The association between client qualities and design team attributes of green building projects. ARPN Journal of Engineering and Applied Sciences. Vol. 9, No. 2, February 2014.

Faridah, S., Ali., Z.A. and Othman, M.Z. (2006). Achieving sustainable construction in the developing countries of South East Asia. Proceedings of the 6th Asia-Pacific Structural Engineering and Construction Conference (APSEC 2006), 5 - 6 September 2006, Kuala Lumpur, Malaysia.

Fazdliel A.I., Wira M.M.S., Ilias, S. and Radzi, I. (2013). Malaysian Housing Developers' Readiness in Green Homes Development. World Applied Sciences Journal 28 (3): 343-352, 2013

Froeschle, L. M. (1999) Environmental Assessment and Specification of Green Building Materials, The Construction Specifier, October 1999, p. 53.

GBI. (2017). Green Building Index. Retrieved August 10, 2017 from www.greenbuildingindex.org.

Glavinich., T.E. (2008). Contractor's Guide Green Building Construction. Hoboken, NJ: John Wiley \& Sons.

Greig, C. C., Cairns, S. and Heynen, H. (2012). The SAGE Handbook of Architectural Theory. Sage: London.

Hayles, C.S. and Kooloos, T. (2008). The challenges and opportunities for sustainable building practices. CIB

W107 Construction in Developing Countries International Symposium. "Construction in Developing Countries: Procurement, Ethics and Technology”. 16 -18 January 2008, Trinidad \& Tobago, W.I..

Hes, D. (2005). Facilitating "Green" building: Turning observation into practice. Doctor of Philosophy, School of Architecture and Design, RMIT University, pp: 253.

Holt, D.T. (2000). The Measurement of Readiness for Change: A Review of Instruments and Suggestions for Future Research. Paper presented at the Annual meeting of the Academy of Management, Toronto, Canada.

Holt, D. T., Armenakis, A. A., Feild, H. S., and Harris, S. G. (2007). Readiness for organizational change: The systematic development of a scale. The Journal of Applied Behavioral Science, 43(2), 232-255.

Kibert, C. J. and Grosskopf, K. (2005) Radical Sustainable Construction: Envisioning Next-Generation Green Buildings, White paper, Next Generation Green Buildings: The Rethinking Sustainable Construction 2006 (RSC06), Sarasota, Florida, USA, 19-22 September 2006.

Lam, P.T.I., Chan, E.H.W., Poon, C.S., Chau, C.K. and Chun, K.P. (2009). Factors affecting the implementation of green specifications in construction. Journal of Environmental Management 91 (2010), pp. 654-661.

Landman, M. (1999). Breaking through the barriers to sustainable building: Insights from building professionals on Government initiatives to promote environmentally sound practices. Unpublished master's thesis, Tufts University.

Lerum, V. (2008). High-Performance Building. John Wiley \& Sons: New Jersey, USA.

Maisarah, A., Mohd Syafiq, F. and Siti Asmahani, S. (2015). Effect of Rice Husk Ash (RHA) on Physical Property and Mechanical Strength of Concrete, Advanced Materials Research, Vol. 1115, pp 150155

Marsh, D. (1999). Results frameworks and performance monitoring. Retrieved from: http://www.childsurvival.com/tools/Marsh/sld001.htm

Meryman, H. and Silman, R. (2004). Sustainable engineering e using specifications to make it happen. Structural Engineering International (IABSE, Zurich, Switzerland), 14(3), 216e219.

Ming-Chin, H. and Chiung-Yu, C. (2006). Introduction to Green Building Policy in Taiwan, CIB W62 Symposium 2006, Taipei, Taiwan. 
Morris, P. and Matthiesen, L.F. (2007). Cost of green revisited: Re-examining the feasibility and cost impact of sustainable design in light of increased market adoption. Davis Langdon, Inc., pp. 3-12, July.

Nazirah, Z.A., Nor'Aini, Y., Ayman, A.E.O. (2013). Enablers and challenges of asustainable housing industry in Malaysia. Construction Innovation, Vol. 13 Issue: 1, pp.10-25.

Ofori, G., Ai Lin, E. and Tjandra, I. (2012). Construction Industry Development Initiatives: Lessons for Ghana from Overseas. International Conference on Infrastructure and Development (pp. 12-17). Kumasi: College of Arch. and Planning, Kwame Nkrumah University of science and Technology.

Olufunto, I. and Olatunde, A. (2013) Sustainable Development through Architecture: A Reflection. International Journal of Engineering and Technology Volume 3 No. 6, June, 2013

Reza, M.E., Marhani, M.A., Yaman, R., Ahmad, A.H., Hanisah, N.N.R. and Hamimah, A. (2011). Obstacles in Implementing Green Building Projects in Malaysia. Australian Journal of Basic and Applied Sciences, 5(12), pp. 1806-1812, 2011

Shari, Z. and Zaky Jaafar, M.F. (2006). Integration and implementation of sustainability in Malaysian architectural education. Proceedings of the $40^{\text {th }}$ Annual Conference of the Architectural Science Association ANZAScA organised by University of Adelaide in Adelaide, Australia on 22-24 November.

Shen, L.Y., Yao, H. and Griffith, A. (2006). Improving environmental performance by means of empowerment of contractors, Management of Environmental Quality: An International Journal, Vol. 17, No. 3, pp. 242-257.

Tan, L.M. (2009). The Development of GBI Malaysia. Retrieved from: http://www.greenbuildingindex.org/Resources/GBI\%20Documents/20090423\%20\%20The\%20De velopment\%20of\%20GBI\%20Malaysia.pdf 